\title{
Chemical composition and in vitro antibacterial activities of traditional medicinal plant: Olea sp.
}

\author{
Suzan Khayat $^{1 *}$, Salha H. Al-Zahrani ${ }^{2}$, Nour Basudan ${ }^{1}$, Nourah H. Al-Zahrani' ${ }^{2}$ Jawaher A. Subahi ${ }^{2}$ \\ ${ }^{1}$ Department of Chemistry, Faculty of Science, King Abdulaziz University, Jeddah, Saudi Arabia \\ ${ }^{2}$ Department of Biology, Faculty of Science, King Abdulaziz University, Jeddah, Saudi Arabia
}

\begin{abstract}
The aim of this work is to study the phytochemical and antibacterial screening of Olea sp. leaves collected from Albaha region in Saudi Arabia. Elements such as Tannins, Steroids, flavonoids, coumarines, terpenoids, anthocyanates and proteins were detected when examining the Olea sp. Plant. The antibacterial activity was carried out by agar well diffusion method; Ampicillin was used as positive control and DMSO as negative control. The minimum inhibitory concentrations (MICs) were determined by using Micro dilution method. The results concluded that the aqueous extract of the plant showed lower antibacterial activities while the Ethanolic extract of Olea sp. was the most active extract against the pathogenic bacteria. The Ethanolic extract of Olea sp. was active against Staphylococcus aureus, Streptococcus pyogenes, E. coli, Pseudomonas aeruginosa and Salmonella sp. with MIC values ranged from 31.2-62.5 $\mu \mathrm{l} / \mathrm{ml}$. The obtained data from the Olea sp. plant confirmed its wide application for therapeutic purposes in alternative therapy.
\end{abstract}

Keywords: Phytochemical screening, Olea sp., Olea europaea, Plant extract, Antibacterial activity.

Accepted on December 05, 2017

\section{Introduction}

The flora in Saudi Arabia has a huge number of medicinal species, which is believed to be more than 1200 species out of $2250[1,2]$. Herbs have been used throughout the history for many purposes such as treating diseases and reducing their symptoms [3]. The Olea europaea complex expands from the Canary Islands and Madeira westwards across the Mediterranean, and southwest Asia to the Sino-Himalayan region, and south through eastern and southern Africa [4]. African Olive is considered a tropical wild olive tree, separated from their Mediterranean relatives and adjusted to different climate conditions [5]. The African wild olive, which was previously, identified as Olea Africana subspecies Cuspidata is currently known as Olea europaea subspecies Africana. The names are selected based on which taxonomy and nomenclature is being used. The most common name is African wild olive and vernacular names are umquma (Zulu, Xhosa and Ndebele) and motlhware (Tswana and Sotho). It belongs to the family Oleaceae. The leaves of Olea europaea subspecies Africana are used as treatments for health issues such as backaches or headaches, eye infections, sore throat, urinary tract infections and kidney problems. They are also functioned as a hypotensive, emollient, febrifuge and styptic [6]. In fact, the leaves of the tree were effectively used for the treatment of malaria in 1854. The extract of olive leaves was also reported to contain a strong antibacterial and antifungal action [7].
In the present study, phytochemical screening of leaves extracts and antibacterial properties against six bacterial strains: Bacillus subtilis, methicillin-resistant Staphylococcus aureus (MRSA), Micrococcus, Escherichia coli, Pseudomonas aeruginosa and Klebsiella pneumonia using agar well diffusion method were investigated [8]. In this study, we discussed the antibacterial activity of a specific plant and locally called AlOttam from Albaha region in Saudi Arabia, we did not find any studies about it. Al-Ottam plant is one of the wild olives belongs to Olea sp., that grow in Al-Baha region. It has the potential to be used as traditional medicine and can be developed into antibacterial (Figure 1).

\section{Materials and Methods}

\section{Chemistry}

A rotatory evaporator (at $400^{\circ} \mathrm{C} / 15$ torr) was used to remove the solvents. Gas chromatography-mass spectroscopy GC-MS was performed using a Hewlett-Packard 5890 series II chromatograph equipped with a 5972 series mass selective detector (MSD) in the electron impact mode $(70 \mathrm{eV})$.

\section{Plant material}

Leaves of Al-Ottam plant Olea sp. were collected from ALBaha region, Saudi Arabia in August-September 2014. The plant was identified partially at the Science College where the 
active materials were extracted. The leaves were grounded after dried while the powder was used in the chemical extraction and its experiments.

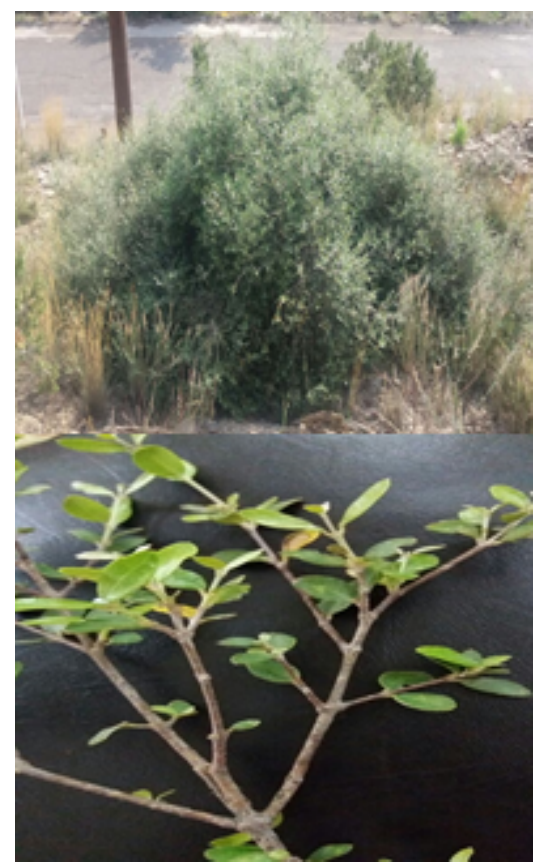

Figure 1. Olea sp. plant.

\section{Preparation of plant extracts}

The dried and powdered form of leaves which consisting of $150 \mathrm{~g}$ was extracted successively using cold percolation system hexane, ethanol, distilled water or chloform (400 ml. for each) for 4 days, using a stirring apparatus [9]. After that, the collected solutions were filtered and the extracts were concentrated to dryness using Rotary vacuum evaporator under reduced pressure at $400^{\circ} \mathrm{C}$ to obtain the respective extracts and then stored in a freeze condition at $-100^{\circ} \mathrm{C}$ until used for further tests.

\section{Preparation of alcoholic extracts for screening}

About $1 \mathrm{gm}$ of dried powder of plant was extracted with about $800 \mathrm{ml}$ of $80 \% \mathrm{v} / \mathrm{v}$ ethanol for 4 days at room temperature using a stirring apparatus. The extract was filtered and the solvent was distilled off in a rotatory evaporator at $400^{\circ} \mathrm{C}$. Then, the extract was concentrated to dry residue in a desiccator over anhydrous Sodium Sulphate. The obtained extracts were filled into sample containers [10].

\section{Phytochemical screening}

Phytochemical screening was performed using standard procedures.

Test for tannins: About one gram of the ethanolic extract was placed in a test tube. A few drops of 5\% ferric chloride was added and observed for a blue-black or a dark green coloration, which was indicative of the existence of tannins [11].
Test for flavonoids (Shinoda Test): One gram of the ethanolic extract was placed in a test tube. A few fragments of magnesium ribbon and drops of concentrated hydrochloric acid were added. The appearance of red or pink color was an indicator of the presence of flavonoids [12].

Test for saponins: In a test tube $0.5 \mathrm{~g}$ of the plant extract was dissolved in boiling water. The content was vigorously shaken to mix thoroughly. The appearance of froth that lasted for 15 min was indicative of the presence of saponins $[13,14]$.

Test for terpenoids (Salkowwski Test): About $2 \mathrm{ml}$ of chloroform was added to $0.5 \mathrm{gm}$ of the extract with $3 \mathrm{ml}$ of conc. $\mathrm{H}_{2} \mathrm{SO}_{4}$ was added carefully to form a layer. The appearance of reddish brown was indicative of the presence of terpenoids [15].

Test for carbohydrates (Molisch's Test): In a test tube, $0.5 \mathrm{~g}$ of the ethanolic extract was placed and dissolved in few drops of water, and then in $0.5 \mathrm{ml}$ of conc. Sulphoric acid was added by the side of the test tube. A red or violet zone is formed at the interphase of the two layers; this indicates the presence of carbohydrates and/or glycosides [16].

Test for anthraquinone (Bontrager's Test): In a test tube, about one gram of the ethanolic extract was placed, then $5 \mathrm{ml}$ of benzene was added. After shaking and filtering, five $\mathrm{ml}$ of $10 \% \mathrm{NH}_{4} \mathrm{OH}$ was added to the tube. Appearance of a pink, red or violet color in the lower phase (ammoniacal layer) was indicating the presence of free anthraquinones [16].

Test for cardiac glycosides (Keller-Kilani Test): Ethanilic extract was mixed with $2 \mathrm{ml}$ of glacial acetic acid containing 1-2 drops of $2 \%$ solution of $\mathrm{FeCl}_{3}$. The mixture was then poured into another test tube containing $2 \mathrm{ml}$ of concentrated $\mathrm{H}_{2} \mathrm{SO}_{4}$. Appearance of brown ring at the interphase was a mark as presence of cardiac glycosides [12].

Test for coumarins: In a test tube, $0.5 \mathrm{~g}$ of moistened plant extract was placed and covered with filter paper moistened with dil. $\mathrm{NaOH}(1 \mathrm{~N})$, then heated on water bath for a few minutes. The filter paper was removed and examined under UV light. Fluorescence was detected by the UV test $(365 \mathrm{~nm})$, yellow fluorescence is indicative for the presence of coumarins [17].

Test for steroids (Liebermann-Burchard Test): In a test tube, $2 \mathrm{ml}$ of acetic acid was added to one gram of ethanolic extract, the solution was cooled in ice followed by adding conc. Sulphoric acid carefully. Color development from violet to blue or bluish-green demonstrated the presence of a steroidal ring [16].

Test for alkaloids: In a test tube, one gram of ethanolic extract was mixed with $2 \mathrm{ml}$ of $1 \% \mathrm{HCl}$ and heated gently. Then, 2-3 drops of Mayer's reagent was added to the mixture. The formation of cream or white precipitate was regarded as positive sign for the presence of alkaloids $[12,14]$.

Test for protein: Millons reagent (mercuric nitrate in nitric acid containing traces of nitrous acid). 
About $1 \mathrm{~g}$ of ethanolic extract was mixed with $2 \mathrm{ml}$ of Millons reagent, white precipitate formed, which transformed to red upon gentle heating. It indicates the presence of amino acids and protein [18]. Table 1 shows the presence of phytochemical screening of ethanolic extract of leaves and seeds of Ruta chalepensis.

\section{Antibacterial activity}

Antibiotic used in this study: Antibiotic powder of Ampicillin was utilized in this study. The antibiotic solution stock was prepared and dilutions made according to the CLSI (Clinical Laboratory Standardization Institute) method or manufacturer's recommendations [19,20].

Test bacterial strains: The clinical bacteria including Staphylococcus aureus, Salmonella sp. No.1 and E. coli No. 1, have been obtained from a Medical Lab., Jeddah, Saudi Arabia, while Streptococcus pyogenes, Pseudomonas aeruginosa, Klebsiella pneumonia No.1, K. pneumonia No.2, E. coli No.2 and Salmonella sp. No2 were obtained from King Abdulaziz Hospital, Jeddah, Saudi Arabia. Moreover, Staphylococcus saprophyticus, Serrratia marcescens, Klebsiella pneumonia, Pseudomonas aeruginosa and Escherichia coli were obtained from King Abdulaziz University, Faculty of Science, Biology Department, Microbiology Lab. Jeddah, Saudi Arabia.

Antimicrobial activity of plant extracts assay: Antimicrobial activities of the plant extracts were tested against different pathogenic bacteria using agar well diffusion method [21]. This medium was composed of $(\mathrm{g} / \mathrm{L})$ : Beef extract, 3; peptone, 5; and $\mathrm{pH}$ 7. Each of the isolates was standardized using colony suspension method. Each strain's suspension was matched with $0.5 \mathrm{McF}$ arland standards to give a resultant concentration of $1.5 \times 10^{8} \mathrm{CFU} / \mathrm{ml}$. The plant extracts susceptibility testing was determined using the modified Kirby-Bauer diffusion technique [22]. Antimicrobial activity was evaluated after incubation at $37^{\circ} \mathrm{C}$ for $24 \mathrm{~h}$ by measuring inhibition zone diameters; the experiments were conducted in triplicate. Pure powder of antibiotic ampicillin was used as positive control, and $40 \%$ DMSO was used as the negative control. The antibiotic stock solution was prepared and dilutions made according to the CLSI (Clinical Laboratory Standardization Institute) method or manufacturer's recommendations $[19,20]$.

Minimal inhibitory concentrations (MIC) of plant extract: Minimum inhibitory concentrations (MICs) were determined as the lowest concentration of antimicrobial agents that will inhibit the visible growth of a microorganism after incubation at $37^{\circ} \mathrm{C}$ for $24 \mathrm{~h}$.

The minimum inhibitory concentration of plant extract against each strain was followed according to a method described in the guidelines of Clinical Laboratory Standard Institute M7-A6 [23]. Briefly, the test was undergone in a 96 well round bottom micro titer plate using standard broth micro dilution approaches. Each antimicrobial plant extracts were serially diluted and about $125 \mu \mathrm{L}$ of each dilution was added to sterilized micro titer plate containing $125 \mu \mathrm{l}$ Luria-Bertani (LB) medium consisting of $(\mathrm{gm} / \mathrm{L})$ : $" 10 \mathrm{~g} /$ tryptone, $5 \mathrm{gm} /$ yeast extract, and $10 \mathrm{gm} / \mathrm{NaCl}$ in $950 \mathrm{ml}$ deionized water" and $\mathrm{pH}$ was $\mathrm{pH} 7.0$, that had freshly prepared a standard number of cells $\left(1.5 \times 10^{8} \mathrm{CFU} / \mathrm{ml}\right.$ for bacteria) and contained some drops of phenol red. Glucose metabolisms were measured by a change in the color of phenol red indicator from red to yellow. The negative control consisted of LB broth with $40 \%$ DMSO, some drops of phenol red and bacterial cell suspension without the plant extract, and the blank control contained only the medium.

Synergistic effect of the plant extracts with different antibiotic: Synergistic effect of leaf extract of Olea sp. in combination with the antibiotic Ampicillin was identified for some pathogenic bacteria. Inoculated agar plates with a particular bacterium were prepared and paper discs of antibiotic were put on the agar surface. The tested plant extract $(10 \mu \mathrm{L})$ was spotted on each antibiotic disc. Finally, all plates were incubated at $37^{\circ} \mathrm{C}$ for $24 \mathrm{~h}$, and the plants were examined for the presence of the inhibition zone around the antibiotic discs.

\section{Statistical analysis}

Statistical analysis was performed by utilizing the Statistical Package for Social Science (OLEA SS for Windows, version 16) (OLEA SS Inc., Chicago, IL, U. S. A). The variability degree of the result is expressed as the mean \pm standard deviation (Mean \pm SD). The significance of the difference between the samples was determined by using Tukey HSD test. The difference was regarded significant when $\mathrm{P}<0.05$ and nonsignificant when $\mathrm{P}>0.05$, where $\mathrm{P}$ is a level of significant.

\section{Results and Discussion}

The results of the qualitative phytochemical screening of Olea sp leaves have been summarized in the Table 1 .

Table 1. Phytochemical constituents of Olea sp leaves.

\begin{tabular}{ll}
\hline Phytoconstituents & Al-Ottam leaves \\
\hline Carbohydrates & ++ \\
\hline Cardiac glycosides & - \\
\hline Alkaloids & + \\
\hline Tannins & +++ \\
\hline Saponins & - \\
\hline Steroids & ++ \\
\hline Flavonoids & +++ \\
\hline Coumarines & + \\
\hline Anthraquinones & + \\
\hline Terpenoids & +++ \\
\hline Anthocyanates & + \\
\hline
\end{tabular}


Protein

$++$

The ethanolic extract of Olea sp leaves was analyzed. The constituents were identified by the familiar GC-MS technique.
The GC chromatograms showed 35 peaks corresponding to the compounds of leaves extract which were characterized by comparing their mass spectra with those of their analogous reported by NIST library (Table 2).

Table 2. Chemical constituents of of ethanolic extract of Olea sp leaves.

\begin{tabular}{|c|c|c|c|c|c|c|}
\hline No. of peak & $\begin{array}{l}\text { Ret. } \\
\text { Time }\end{array}$ & $\begin{array}{l}\text { Suggest. } \\
\text { Comp. }\end{array}$ & Structher Comp. & M.W. & M.F. & Area\% \\
\hline 1 & 3.06 & Methyl-8,11-octadecadiynoate & & 290 & $\mathrm{C}_{19} \mathrm{H}_{30} \mathrm{O}_{2}$ & 0.03 \\
\hline 2 & 5.04 & Neoheptanol & & 116 & $\mathrm{C}_{7} \mathrm{H}_{16} \mathrm{O}$ & 1.32 \\
\hline 3 & 5.33 & $\begin{array}{l}\text { 2Furanmethanol,tetrahydro-5- } \\
\text { methyl,Trans }\end{array}$ & & 116 & $\mathrm{C}_{6} \mathrm{H}_{12} \mathrm{O}_{2}$ & 0.60 \\
\hline
\end{tabular}

$4 \quad 12.08 \quad$ Camphor

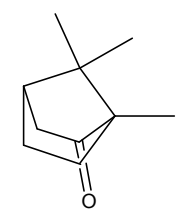

152

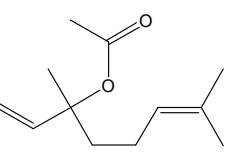

196

$\mathrm{C}_{12} \mathrm{H}_{20} \mathrm{O}_{2}$

1.60

16.08 Linalyl acetate

1,2,3,4-Tetrahydro1,1,4,4-

tetramethyl-phenylanthracene

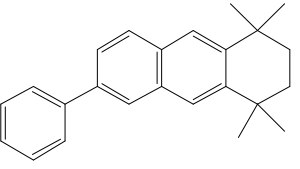

314

$\mathrm{C}_{24} \mathrm{H}_{26}$

0.80

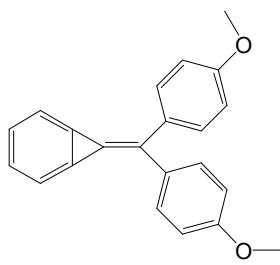

-(bis(4-methoxyphenyl)

methylene)-7- $\mathrm{H}-$

bicyclo[4.1.0]hepta-1,3,5-triene

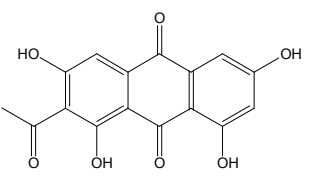

314

$\mathrm{C}_{16} \mathrm{H}_{10} \mathrm{O}_{7}$

0.03

2-Acetyl-1,3,6,8-

tetrahydroxyanthraquinone

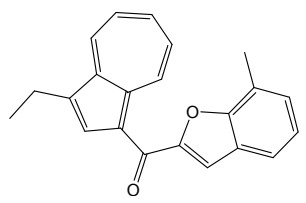

314

$\mathrm{C}_{22} \mathrm{H}_{18} \mathrm{O}_{2}$

0.59 


\begin{tabular}{|c|c|c|c|c|c|}
\hline 10 & 39.06 & $\begin{array}{l}\text { Acetic acid-10-hydroxy-12- } \\
\text { amethyl-7-oxo-1,2,3,3A,3B, } \\
4,5,7,8,9,10,11,12,12-\text { ATETRA }\end{array}$ & 332 & $\mathrm{C}_{20} \mathrm{H}_{28} \mathrm{O}_{4}$ & 0.25 \\
\hline 11 & 39.51 & $\begin{array}{l}\text { 3,7,11,15-Tetramethyl-2- } \\
\text { hexadecen-1-ol }\end{array}$ & 296 & $\mathrm{C}_{20} \mathrm{H}_{40} \mathrm{O}$ & 0.66 \\
\hline 12 & 41.97 & Hexadecanoic acid, methyl ester & 270 & $\mathrm{C}_{17} \mathrm{H}_{34} \mathrm{O}_{2}$ & 0.82 \\
\hline 13 & 43.09 & $\begin{array}{l}\text { 1,2-Benzenedicarboxylicacid, butyl } \\
\text { octyl ester }\end{array}$ & 334 & $\mathrm{C}_{20} \mathrm{H}_{30} \mathrm{O}_{4}$ & 0.05 \\
\hline 14 & 43.13 & $\begin{array}{l}\text { Methyl 1,3-dihydro-2- } \\
\text { Hisobenzofuran-4-carboxylate }\end{array}$ & 178 & $\mathrm{C}_{10} \mathrm{H}_{10} \mathrm{O}_{3}$ & 0.10 \\
\hline 15 & 44.07 & Isochiapin B & 346 & $\mathrm{C}_{19} \mathrm{H}_{22} \mathrm{O}_{6}$ & 0.19 \\
\hline 16 & 45.95 & $\begin{array}{l}\text { Ethyl } \\
\text { (methylenedioxy)phenyl]-2- } \\
\text { penten1oate }\end{array}$ & 248 & $\mathrm{C}_{14} \mathrm{H}_{16} \mathrm{O}_{4}$ & 3.29 \\
\hline 17 & 47.13 & $\begin{array}{l}\text { 6,9-Octadecadienoic acid, methyl } \\
\text { ester }\end{array}$ & 294 & $\mathrm{C}_{19} \mathrm{H}_{34} \mathrm{O}_{2}$ & 0.35 \\
\hline 18 & 47.31 & $\begin{array}{l}\text { Trans-13-Octadecenoicacid, } \\
\text { methyl ester }\end{array}$ & 296 & $\mathrm{C}_{19} \mathrm{H}_{36} \mathrm{O}_{2}$ & 6.04 \\
\hline 19 & 48.14 & $\begin{array}{l}\text { Heptadecanoic acid, } \\
\text { methyl,methyl ester }\end{array}$ & 298 & $\mathrm{C}_{19} \mathrm{H}_{38} \mathrm{O}_{2}$ & 0.61 \\
\hline 20 & 49.56 & $\begin{array}{l}\text { 5-Isopropyl4methyl-2- } \\
\text { hydroxybenzophenone }\end{array}$ & 254 & $\mathrm{C}_{17} \mathrm{H}_{18} \mathrm{O}_{2}$ & 41.98 \\
\hline
\end{tabular}


$2150.09 \quad$ 4-Methoxy-2,6-dimethyl6[(E)styryl]Cyclohexa-2,4-dienone

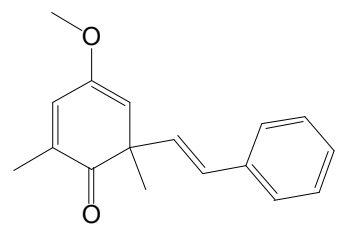

254

$\mathrm{C}_{17} \mathrm{H}_{18} \mathrm{O}_{2}$

0.21

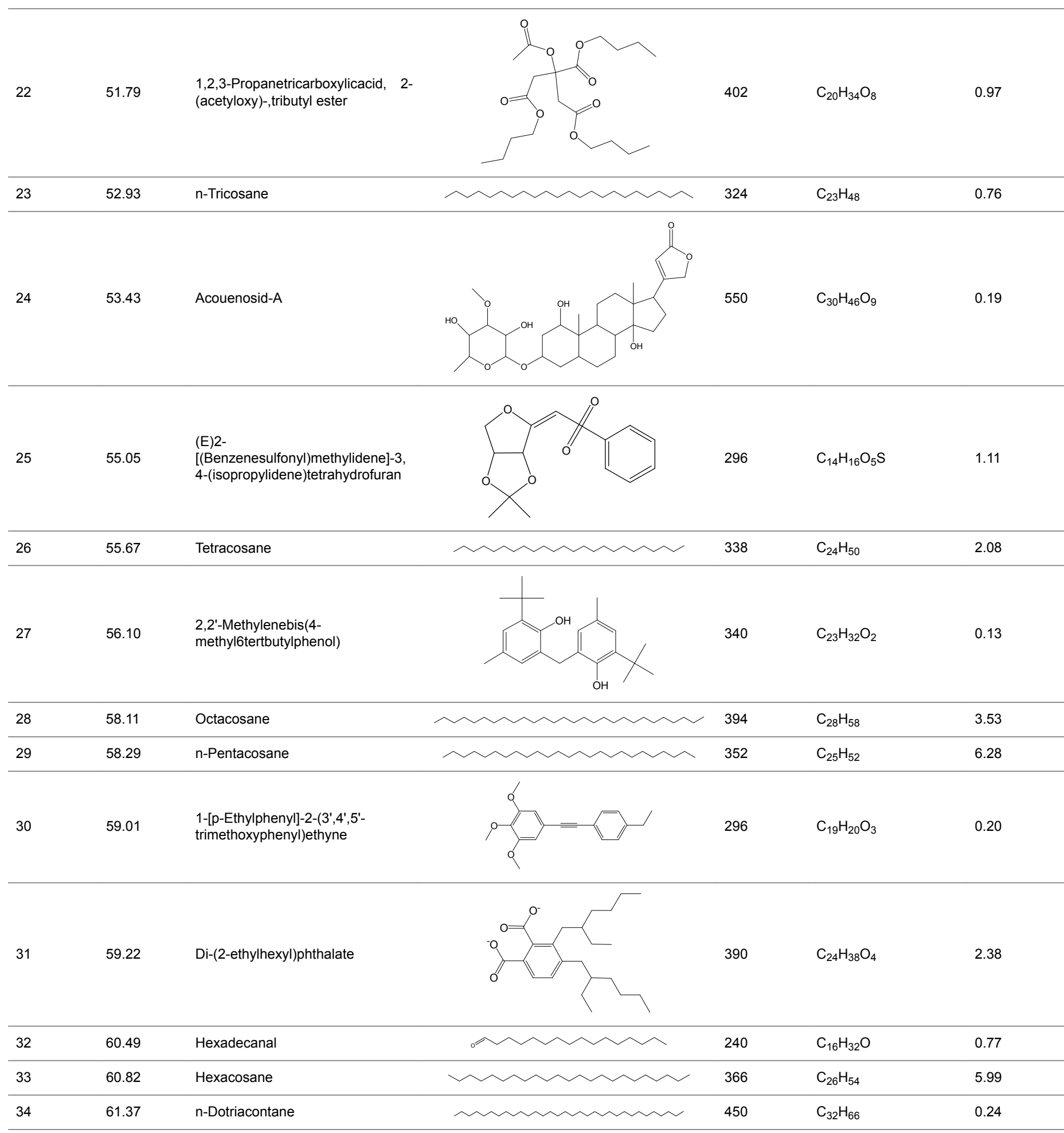




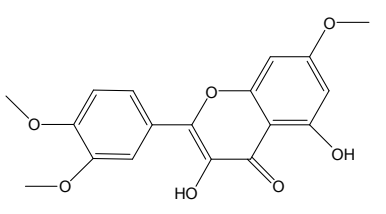

The antimicrobial activity of the plant extract was measured as the mean diameter of the inhibition zone $(\mathrm{mm})$ on Nutrient agar medium and using Agar Well Diffusion Assay. The water extract of Olea sp. leaves was active against $S$. aureus, $S$. saprophyticus and $S$. pyogenes with mean inhibition zone diameter 16.0, 18.5 and $15.8 \mathrm{~mm}$, respectively (Table 3).

Chloroform extract of Olea sp. was active against S. aureus, and $S$. pyogenes with mean inhibition zone diameters 20.3 , and $20.0 \mathrm{~mm}$, respectively and no antibacterial activity was recorded against S. Saprophyticus. Acetone leave extract of Olea sp. was active against $S$. aureus, S. saprophyticus and $S$. pyogenes and the inhibition zone diameters were 16.3, 18.6 and $19.5 \mathrm{~mm}$, respectively, also extraction with Ethanol showed the maximum an antibacterial activities against all the three tested Gram-positive bacteria with inhibition zone diameter about $25.0 \mathrm{~mm}$ (Figure 2A), but extraction of Olea sp. leave powder with Methanol showed less antibacterial activity against the three previous mentioned bacteria, For the tested gram positive bacteria, the bacterial index for Ethanol extract of Olea sp. was $>$ Chloroform extract $>$ Acetone extract $>$ Methanol extract.

Table 3. The antibacterial activity of Olea sp. extracts against some Gram positive bacteria.

\begin{tabular}{|c|c|c|c|c|c|}
\hline \multirow[t]{2}{*}{ Bacterial isolates } & \multicolumn{5}{|c|}{ Diameter of inhibition zone in ( $\mathrm{mm}$ ) } \\
\hline & water & Chloroform & $\begin{array}{l}\text { Aceton } \\
\mathrm{e}\end{array}$ & Ethanol & $\begin{array}{l}\text { Methano } \\
\text { I }\end{array}$ \\
\hline Staphylococcus aureus & $\begin{array}{l}16.0 \\
1.7^{*}\end{array}$ & $20.3 \pm 1.4^{*}$ & $\begin{array}{l}16.3 \\
1.9^{*}\end{array}$ & $\begin{array}{l}25.3 \pm \\
2.1^{*}\end{array}$ & $\begin{array}{l}14.3 \\
1.5^{*}\end{array}$ \\
\hline $\begin{array}{l}\text { Staphylococcus } \\
\text { saprophyticus }\end{array}$ & $\begin{array}{l}18.5 \\
1.6^{*}\end{array}$ & ND & $\begin{array}{l}18.6 \pm \\
3.1^{*}\end{array}$ & $\begin{array}{l}25.1 \pm \\
1.0^{*}\end{array}$ & $\begin{array}{l}16.2 \\
1.8^{*}\end{array}$ \\
\hline
\end{tabular}

\begin{tabular}{|c|c|c|c|c|c|}
\hline Streptococcus pyogenes & $\begin{array}{l}15.8 \\
1.4^{*}\end{array}$ & $20 \pm 1.7^{*}$ & $\begin{array}{l}19.5 \\
4.1^{*}\end{array} \pm$ & $\begin{array}{l}25.0 \\
1.7^{*}\end{array} \quad \pm$ & $\begin{array}{l}14.3 \\
1.9^{*}\end{array}$ \\
\hline${ }^{* *}$ Bacterial index & 16.7 & 20.1 & 18.1 & 25.1 & 14.9 \\
\hline \multicolumn{6}{|c|}{$\begin{array}{l}\text { ** Bacterial index: Total activities against bacteria divided by the number of the } \\
\text { tested bacteria, }{ }^{*}: \text { Significant results at } p \leq 0.05 \text {, compared to control (DMSO), } \\
\text { ND: Not Detected }\end{array}$} \\
\hline
\end{tabular}

Water extract of Olea sp. has antibacterial activity against some of tested Gram-negative bacteria, E. coli ATCC 25922, E. coli No.2, K. pneumonia No.1 and $K$. pneumonia No.2 but no antibacterial activity was recorded against $E$. coli No.1, $P$. aeruginosa ATCC 27583, Salmonella sp. No.1, Salmonella sp. No. 2 and Serrratia marcescens (Table 3). Results in Table 3 showed that all the organic solvent of Olea sp. extracts have antibacterial activity against the tested gram-negative bacteria.

The Chloroform extract showed antibacterial activities with inhibition zones diameter ranged from 14-23 $\mathrm{mm}$. The acetone extract of Olea sp. was active against all the tested Gram negative bacteria with mean inhibition zone diameters ranged from 17.3-22.7 $\mathrm{mm}$. The maximum antibacterial activity was against E. coli No.1 Figure 2B, similarly, the methanolic extract of Olea sp. leaves was active against all the tested Gram-negative bacteria except $K$. pneumonia No.1 and $P$. aeruginosa ATCC 27583.

For the tested Gram-negative bacteria, the bacterial index for ethanol extract of Olea $\mathrm{sp}$. was $>$ Chloroform extract $>$ Acetone extract $>$ Methanol extract. Statistically analysis of the results using student t-test indicated that the 4 organic extracts of Olea sp. affect significantly the antibacterial activity against tested Gram-positive or Gram-negative bacteria compared to control (DMSO).

Table 4. The antibacterial activity of Olea sp. extracts against tested Gram negative bacteria.

\begin{tabular}{|c|c|c|c|c|c|}
\hline \multirow{2}{*}{ Bacterial isolates } & \multicolumn{5}{|c|}{ Diameter of inhibition zone (in $\mathrm{mm}$ ) } \\
\hline & Water & Chloroform & Acetone & Ethanol & Methanol \\
\hline E. coli ATCC 25922 & $16.6 \pm 0.1$ & $15.0 \pm 1.0^{*}$ & $20.5 \pm 2.9^{*}$ & $19.6 \pm 1.5^{*}$ & $19.3 \pm 1.4^{*}$ \\
\hline E. coli No.1 & ND & $16.5 \pm 2.9^{*}$ & $22.7 \pm 1.8^{*}$ & $22.9 \pm 1.9^{*}$ & $15.6 \pm 1.6^{*}$ \\
\hline E. coli No.2 & $15.9 \pm 1.1^{*}$ & $14.0 \pm 1.0^{*}$ & $19.7 \pm 1.18$ & $17.6 \pm 1.0^{*}$ & $14.6 \pm 1.0^{*}$ \\
\hline Klebsilla pneumonia No.1 & $16.8 \pm 1.0^{*}$ & $17.8 \pm 1.9^{*}$ & $19.6 \pm 3.98$ & $19.6 \pm 1.0^{*}$ & ND \\
\hline Klebsilla pneumonia No.2 & $18.0 \pm 0.9^{*}$ & $13.5 \pm 1.0^{*}$ & $18.4 \pm 1.58$ & $18.9 \pm 2.9^{*}$ & $13.3 \pm 3.2^{*}$ \\
\hline Pseudomonas aeruginosa ATCC 27583 & ND & $19.6 \pm 2.3^{*}$ & $21.5 \pm 2.9^{*}$ & $23.2 \pm 4.1^{*}$ & ND \\
\hline Salmonella sp. No.1 & ND & $23.0 \pm 2.0^{*}$ & $17.3 \pm 3.0^{*}$ & $19 \pm 1.6^{*}$ & $15.3 \pm 2.3^{*}$ \\
\hline
\end{tabular}




\begin{tabular}{|c|c|c|c|c|c|}
\hline Salmonella sp. No.2 & ND & $19.6 \pm 3.1^{*}$ & $18.3 \pm 1.0^{*}$ & $21.2 \pm 1.8^{*}$ & $17.1 \pm 2.9^{*}$ \\
\hline Serrratia marcescens & ND & $18.3 \pm 2.0^{*}$ & $18.2 \pm 1.0^{*}$ & $20 \pm 1.0^{*}$ & $18.5 \pm 1.8^{*}$ \\
\hline **Bacterial index & 16.8 & 17.5 & 19.6 & 20.2 & 16.2 \\
\hline
\end{tabular}

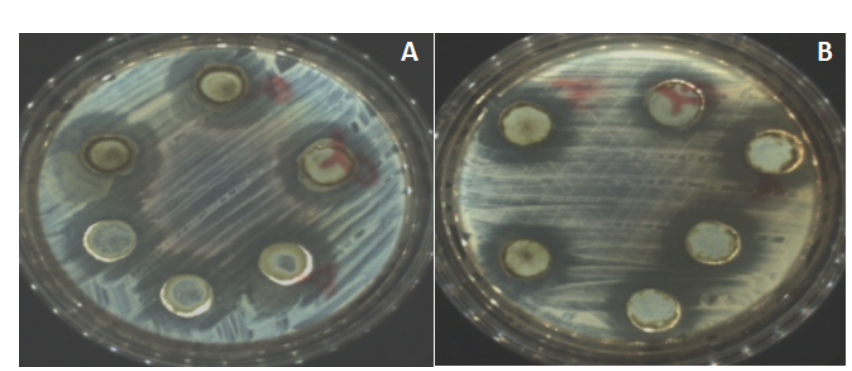

Figure 2. The antibacterial activity of ethanol extract of Olea sp. on S. aureus (A), and E. coli No.2. (B).

The ethanolic extract of Olea sp. was the most active extract against the tested Gram-positive and Gram-negative bacteria compared to other obtained extracts Chloroform, Acetone, and methanol thus, the active plant extracts. Ethanol extract of Olea $\mathrm{sp}$. was selected for more detail studies. The minimal inhibitory concentration (MIC) of the selected extract was determined for the test pathogenic Gram-positive and Gramnegative bacteria using Microdilution method. The MIC was ranged from $31.2-62.5 \mu \mathrm{g} / \mathrm{ml}$. The calculated MIC for $S$. aureus was $31.2(\mu \mathrm{g} / \mathrm{ml})$ and higher MIC value $(62.5 \mu \mathrm{g} / \mathrm{ml})$ was recorded for both $S$. pyogenes and S. saprophyticus. The MIC for the commercial antibiotic Ampicillin was $3 \mu \mathrm{g} / \mathrm{ml}$ for $S$. aureus and $S$. pyogenes while it was $1.5 \mu \mathrm{g} / \mathrm{ml}$ for $S$. saprophyticus (Table 4).

Plants have been consumed in medicine to treat infectious diseases and to improve human's health. Traditionally, many plants with medicinal features are used to treat bacterial pathogens [24]. In both developed and underdevelopment countries, plant materials, which are the main sources of natural products, have a variety of antibiotic resistant bacteria and fewer negative impacts [25]. Pereira et al. [7] indicated that this antibacterial and antifungal actions of olive leaves are due to the phenolic compounds including caffeic acid, verbascoside, oleuropein, luteolin 7-Oglucoside, rutin, apigenin 7-O-glucoside and luteolin 4'-O-glucoside The authors thus suggested a potential use of the extract from olive leaves as nutraceuticals, particularly as a source of phenolic compounds. In Saudi Arabia, Olea europaea subsp. cuspidata had been used in traditional medicines for many years. It was used in hemorrhages treatment and fevers as a metabolism inducer and bile flow stimulator. It was also used as astringent, antiseptic and a general tonic. Olea sp. leaves were selected for the current study to examine their antibacterial activities against many pathogenic bacteria. The obtained results indicated that the aqueous extracts of the plant showed lower antibacterial activities while the ethanolic extract of Olea sp. was the most active extracts against different pathogenic bacteria.

The weak inhibitory effect of the aqueous extracts of Olea sp. against all the tested Gram-negative and Gram-positive bacteria may be due to the solubility of the active components in hot water. On contrast, Jagtap and Karkera reported that the aqueous extract at different concentrations (6-30\%) had maximum anti-bacterial potential on $S$. mutans and the inhibition zone diameter increased by increasing the concentration of the extract [26]. Moreover, many authors reported that aqueous extract has a high polarity, readily available and almost all the compounds of the plant dissolve in it without affecting it is biological properties [27] and such extracts had an inhibitory effect on the growth of microorganisms. These controversial results can be explained by the different techniques used for extraction. The sensitivity and the accuracy of the antimicrobial test, the concentration and the effectiveness of the constituents of the extracts, the conditions of collections, season, storage and the preservation method of the extracts all are factors affecting the antimicrobial activity of the plant extracts. Similar to our results, water extract of Aillium sativum showed no growth inhibition of the E. coli and K. pneumonia.

Many others reported that extraction with organic solvents was more effective as compared to aqueous extraction. While many previous studies indicated that methanol extracts the antimicrobial substances from medicinal plants better than water and ethanol [28]. Our findings agree with other observations [29] who demonstrated that the ethanolic plant extract exhibited the maximum zone of inhibition against some test bacteria compared to other extracts. Similarly, Masoud and Gouda used water, $80 \%$ ethanol or n-hexane for plant extraction [30]. The antibacterial activity of the used plant extract depends on the chemical content of plant extracts which differs depending on the nature of the solvent utilised in the extraction procedure [31]. This conflict can explain that the better removal of antimicrobial compounds from various medicinal plants may require different solvents.

The MIC of the Ethanol extract of Olea sp. was determined for the tested Gram-negative bacteria (Table 4). It was ranged from 31.2-62.6 $\mu \mathrm{g} / \mathrm{ml}$. The calculated MIC was $31.2 \mu \mathrm{g} / \mathrm{ml}$ for $K$. pneumonia No.1, $K$. pneumonia No.2, $P$. aeruginosa ATCC 27583, E. coli No.2 and E. coli ATCC 25922 while higher MIC value $(62.5 \mu \mathrm{g} / \mathrm{ml})$ was recorded for both Salmonella sp. No.2 and E. coli No.1. The calculated MIC value was $50 \mu \mathrm{g} / \mathrm{ml}$ for both Salmonella sp. No.1 and Serrratia marcescens (Figure 2). 
The mixture of the antibiotic (Ampicillin) and Olea sp. was prepared $(1: 1 \mathrm{~V} / \mathrm{V})$ and MIC was recorded for the tested Gram positive bacteria. It was found that the calculated MIC was 3 $\mu \mathrm{g} / \mathrm{ml}$ for the 3 tested Gram-positive bacteria. The index values were 1.1 for $S$. aureus and 2.05 for both $S$. saprophyticus and $S$. pyogenes (Table 4). Also the mixture of the antibiotic (Ampicillin) and Olea sp. was prepared (1:1 V/V) and MIC was recorded for the tested Gram-negative bacteria. It was found that the calculated MIC was $5 \mu \mathrm{g} / \mathrm{ml}$ for all the tested Gram negative bacteria, except E. coli No.1 and Serrratia marcescens, it was $10 \mu \mathrm{g} / \mathrm{ml}$.

Table 4. Minimal inhibitory concentration (MIC) of the Ethanol extract of Olea sp., the antibiotic Ampicillin and their combination on the tested bacteria

\begin{tabular}{|c|c|c|c|c|}
\hline Bacterial isolates & $\begin{array}{l}\text { MIC } \\
\text { Olea sp. } \\
(\mu \mathrm{g} / \mathrm{ml})\end{array}$ & $\begin{array}{l}\text { Ampicillin } \\
(\mu \mathrm{g} / \mathrm{ml})\end{array}$ & $\begin{array}{l}\text { Ampicillin } \\
+ \text { Olea sp. }\end{array}$ & $\begin{array}{l}\text { Index } \\
\text { values }\end{array}$ \\
\hline E. coli ATCC 25922 & 31.2 & 10 & 5 & 0.67 \\
\hline E. coli No.1 & 62.5 & 10 & 10 & 1.17 \\
\hline E. coli No.2 & 31.2 & 5 & 5 & 1.17 \\
\hline Klebsilla pneumonia No.1 & 31.2 & 5 & 5 & 1.17 \\
\hline Klebsilla pneumonia No.2 & 31.2 & 10 & 5 & 0.67 \\
\hline $\begin{array}{l}\text { Pseudomonas aeruginosa } \\
\text { ATCC } 27583\end{array}$ & 31.2 & 10 & 5 & 0.67 \\
\hline Salmonella sp. No.1 & 50 & 3.12 & 5 & 1.8 \\
\hline Salmonella sp No.2 & 62.5 & 12.5 & 5 & 0.48 \\
\hline Serrratia marcescens & 50 & 12.5 & 10 & 1.0 \\
\hline Staphylococcus aureus & 31.2 & 3 & 3 & 1.1 \\
\hline $\begin{array}{l}\text { Staphylococcus } \\
\text { saprophyticus }\end{array}$ & 62.5 & 1.5 & 3 & 2.05 \\
\hline Streptococcus pyogenes & 62.5 & 3 & 3 & 2.05 \\
\hline
\end{tabular}

The minimal inhibitory concentrations (MICs) were determined using Micro-dilution method. This method used by many authors to determine the MIC for many plant extracts [32]. The selected plant extracts were found to be effective on the standard and clinical bacterial isolates. The ethanolic extract of Olea sp. was active against some Gram-positive and Gram-negative bacteria with MIC values ranged from 31.2-62.5 $\mu \mathrm{l} / \mathrm{ml}$.

Concerning this study, an Olea sp. leaf extract was broadspectrum in action, showing significant activity against $S$. aureus, S. saprophyticus, S. pyogenes, E. coli, P. aeruginosa ATCC 27583, Salmonella sp. and Serrratia marcescens. While, Sudjanaa et al. reported that Olea europaea var sylvestris leaf extract was broad-spectrum in action against Helicobacter pylori, Clostridium jejuni, S. aureus, and MRSA [33]. They added that leaf extract may have a role in regulating the composition of the gastric flora by selectively reducing levels of $H$. pylori and C. jejuni. Combination of antibiotics with plant extracts therapy or combined therapy against resistant microorganisms may result in new methods of treating infectious diseases [34]. Combination therapy is helpful and useful for patients with severe infections caused by drugresistant pathogens. The mode of action of combination therapy significantly differs from that of the same drugs acting individually; therefore, the selection of an appropriate combination is crucial and essential which requires understanding the potential interaction between the plant extracts and antimicrobial agents $[35,36]$.

The researchers investigated the synergistic capacity of the plants, other natural products, or independent of the antimicrobial activity they have. The possible activities of substances found in plant extracts on ribosome structure and bacterial enzymes inhibition appear to be related with synergism profile between plant extracts and the inhibitions of protein synthesis, however, the understanding of synergism mechanism is fundamental to development of pharmacological agents to treat diseases by various bacteria using medicinal plants [37]. Few studies have been conducted on synergism thus, in this research, we evaluated in vitro the antibacterial activity synergism of Olea sp. extract and Ampicillin $(1: 1 \mathrm{~V} / \mathrm{V})$ against bacterial pathogens. Index value was between from 0.48 and 2.01. A synergic effect of the antibiotic chloramphenicol with the ethanolic extracts of stem and leaf of Olea europaea has been reported [38]. The mixture of leaf extract of Olea sp. created the highest inhibition zone (34.5 $\mathrm{mm}$ ) against Staphylococcus aureus.

\section{Conclusion}

The tested extracts of all Olea sp. plant was found to be active against pathogenic bacteria used in this study and consequently led to serious health issues. To conclude, it is important to note that future studies on this type of plant should be carried out in order to identify it. Besides, different solvents such as ethanol, methanol, acetone, etc can enhance the anti-microbial efficacy. Finally, anti-bacterial activity of this medicinal herb, if translated into clinical practice would result in the development of indigenous, chemical free, cost-effective products, which can be integrated into various pathogenic bacteria treatments.

\section{References}

1. Youssef R. Medicinal and non-medicinal uses of some plants found in the middle region of Saudi Arabia 2013; 7: 2501-2513.

2. Rahman MA, Mossa JS, Al-Said MS, Al-Yahya MA. Medicinal plant diversity in the flora of Saudi Arabia 1: a report on seven plant families. Fitoterapia 2004; 75: 149-161.

3. Shinde B, Mulay Y. Phytochemical analysis and antibacterial properties of some selected indian medicinal plants. Int J Curr Microbiol App Sci 2015; 4: 228-235.

4. Green PS, Kupicha FK. Notes on the genus Olea. Kew Bulletin 1979. 
5. Olive ZD. Olea europaea (Oleaceae). In: Smartt J and Simmonds NW (eds.) Evolution of crop plants (2nd Edn), Longman, UK, 1995.

6. Somova L, Shode F, Ramnanan P, Nadar A. Antihypertensive, antiatherosclerotic and antioxidant activity of triterpenoids isolated from Olea europaea, subspecies africana leaves. J Ethnopharm 2003; 84: 299-305.

7. Pereira AP, Ferreira IC, Marcelino F, Valentão P, Andrade PB, Seabra R. Phenolic compounds and antimicrobial activity of olive (Olea europaea L. Cv. Cobrançosa) leaves. Molecules 2007; 12: 1153-1162.

8. Gumgumjee N, Hajar A. Antimicrobial Activities and phytochemical properties of Saudi Olea europaea subsp. Cuspidate. Life Scie J 2014; 11: 232-237.

9. Duraipandiyan V, Ignacimuthu S. Antibacterial and antifungal activity of Flindersine isolated from Toddalia asiatica (L) Lam. a traditional medicinal plant. J Ethnopharmacol 2009; 123: 494-498.

10. Khayyat S, Alkattan M. Phytochemical screening and antimicrobial activities of Costus speciosus and Sea qust. Biomed Res 2017; 28: 389-393.

11. Cuilel I. Methodology for the analysis of vegetables and drugs. Chemical Industry Division, NNIDO Romania, 1994.

12. Yadav R, Munin A. Phytochemical analysis of some medicinal plants. J Phytology 2011; 3: 10-14.

13. Nisa S, Bibi Y, Waheed A, Zia M, Sarwar S, Sabbir A, Chaudhary M. Evaluation of anticancer activity of Debregeasia Salicifolia extract against estrogen receptor positive cell line. Afr J Biotechnol 2011; 10: 990-995.

14. Ranjit P, Santhipriya T, Nagasri S, Chowdary Y, Pasumarthy N. Prelininary phytochemical screening and antibacterial activities of ethanolic extract of calotropisprocera flowers against human pathogenic strains. Asian J Pharm Clinic Res 2012; 5: 127-131.

15. Khan F, Iqbal H, Shahid F, Majed A, Muhammad A, Inayat U. Phytochemical screening of some Pakistanian medicinal plants. Middle-East J Sci Res 2011; 8: 575-578.

16. Usman H, Abdulrahman F, Usman A. Qualitative phytochemical screening and in vitro antimicrobial effects of methanol stem bark extract of Ficus thonningii (Moraceae). Afr J Tradit Complement Altern Med 2009; 6: 289-295.

17. Pochapski M, Fosquiera E, LuísAntônio E, Elizabete S, Paulo V, Fábio A, Francisco C. Phytochemical screening, antioxidant, and antimicrobial activities of the crude leaves' extract from Ipomoea batatas (L.) Lam. Pharmacogn Mag 2011; 7: 165-170.

18. Debela A. Manual for phytochemical screening of medicinal plants. Ethiopian Health and Nutrition Research Institute, Addis Ababa, Ethiopia, 2002.

19. NCCLS. Methods for dilution antimicrobial susceptibility tests for bacteria that grow aerobically, 4th ed.; Approved Standard M7-A4; NCCLS: Wayne, PA, USA, 1997.
20. Cheesbrough M. District laboratory practice in tropical counters - Part 2. Cambredge university Press, Cambredge, UK, 2002.

21. Gills LS. Ethno medical uses of plants in Nigeria. Ilupeju Press Lt; 1992: 165-250.

22. Bauer AW, Kirby WM, Sherris JC, Turck M. Antibiotic susceptibility testing by a standardized single disk method. Am J Clin Pathol 1966; 45: 493-496.

23. Clinical and Laboratory Standard Institute (CLSI). Performance standards for antimicrobial susceptibility testing eighteenth informational supplement, 2008: M100S18; CLSI: Wayne, PA, USA.

24. Cowan MM. Plant products as antimicrobial agents. Clin Microbiol Rev 1999; 12: 564-582.

25. Ozoula IR, Idogun SE, Tafamel GE. Acute and sub-acute toxicological assessment of aqueous leaf extract of Bryophyllum pinnatum (Lam) in Sprague-Dawley rats. Am J Pharmacol Toxical 2010; 5: 145-151.

26. Jagtap AG, Karkera SG. Potential of the aqueous extract of Terminalia chebula as an anticaries agent. J Ethnopharmacol 1999; 68: 299-306.

27. Erturk O. Antibacterial and antifungal effects of alcoholic extracts of 41 medicinal plants growing in Turkey. Czech J Food Sci 2010; 28: 53-60.

28. El Sayed HE, Aly MM. Antibacterial activities of six medicinal plants used traditionally by saudi people to treat common diseases. British Biotechnol J 2014; 4: 499-510.

29. Sulieman AME, Boshra IMO, El Khalifa EAA. Nutritive value of clove (Syzygium aromaticum) and detection of antimicrobial effect of its bud oil. Res J Microbiol 2007; 2: 266-271.

30. Masoud EA, Gouda HA. Effect of some natural plant extracts against gram negative bacteria in Njran Area, Saudi Arabia. Egypt Acad J Biolog Sci 2012; 4: 85-92.

31. Jules ES, Ellison AM, Gotelli NJ, Lillie S, Meindl GA, Sanders NJ, Young AN. Influence of fire on a rare serpentine plant assemblage: A 5-year study of Darlingtonia fens. Am J Bot 2011; 98: 801- 811.

32. Jadaun GP, Agarwal C, Sharma H, Ahmed Z, Upadhyay P, Faujdar J, Gupta AK, Das R, Gupta P, Chauhan DS, Sharma VD, Katoch VM. Determination of ethambutol MICs for Mycobacterium tuberculosis and Mycobacterium avium isolates by resazurin microtitre assay. J Antimicrob Chemother 2007; 60: 152-155.

33. Sudjanaa AN, D’Oraziob C, Ryan V, Rasoold N, Ngd J, Islamd N, Rileya TV, Katherine A. Antimicrobial activity of commercial Olea europaea (olive) leaf extract. Int J Antimicrob Agents 2009; 33: 461-463.

34. Olayinka A, Aiyegoro A, Okoh I. Preliminary phytochemical screening phytochemical screening and In vitro antioxidant activities of the aqueous extract of Helichrysum longifolium DC. BMC Complement Alternative Med 2010; 14: 10-21.

35. Levy SB. The antibiotic paradox: How the misuse of antibiotics destroys their curative powers. Cambridge, MA: Perseus Publishing 2002: 376. 
36. Usha PTA, Jose S, Nisha AR. Antimicrobial drug resistance-a global concern. Veterinary World 2010; 3: 138-139.

37. Betoni JEC, Mantovani RP, Barbosa LN, Di Stasi LC, Fernandes A Jnr. Synergism between plant extract and antimicrobial drugs used on Staphylococcus aureus diseases. Mem Inst Oswaldo Cruz Rio de Janeiro 2006; 101: 387-390.

38. Ahmed Z, Khan S, Khan M, Tanveer A, Lone Z. Synergistic efficacy of Olea europaea ethanolic extracts, chloramphenicol and penicillin against Staphylococcus aureus. Nanobiotechnica Universale 2010; 1: 29-37.

\section{*Correspondence to}

Suzan Khayat

Department of Chemistry

Faculty of Science

King Abdulaziz University

Saudi Arabia 